\title{
Soil erosion risk assessment in Sanjal watershed, Jharkhand (India) using geo-informatics, RUSLE model and TRMM data
}

\author{
Dipanwita Dutta $^{1} \cdot$ Subhasish Das $^{2} \cdot$ Arnab Kundu $^{3} \cdot$ Afrin Taj $^{1}$
}

Received: 28 July 2015/Accepted: 16 September 2015/Published online: 3 November 2015

(C) Springer International Publishing Switzerland 2015

\begin{abstract}
Soil erosion is a serious environmental issue in many parts of India. As the removal of fertile top soil has direct impact upon productivity of crops, there is a need to assess the potential risk of soil loss and take preventive measures. In order to study this issue, a remarkable number of soil erosion models have come up in the last few decades. Among them, RUSLE has adopted by many researchers for estimating the areas of potential soil erosion risk. Unfortunately, these researches have long been used sparsely distributed meteorological station based data for calculating rainfall erosivity factor. Since, rainfall erosivity is one of the major driving forces of soil loss, spatial variation of rainfall data should be considered during estimation of potential rainfall. In this context, the present study aims to predict potential risk of soil erosion in Sanjal watershed of Jharkhand using TRMM data. The study reveals a close agreement between spatial patterns of potential soil erosion and slope in the watershed. The predicted amount of soil loss as estimated by RUSLE is ranging between 0.2 and $61.4 \mathrm{t} \mathrm{ha}^{-1}$ year $^{-1}$. Although about half of the total area having very low risk of soil erosion, few portions specially areas with steep slope has high risk of soil loss. The incorporation of TRMM data has
\end{abstract}

Arnab Kundu

arnknd@gmail.com

1 Department of Remote Sensing and GIS, Vidyasagar University, West Bengal, India

2 Department of Geology and Geophysics, Indian Institute of Technology, Kharagpur, West Bengal, India

3 Centre of Atmosphere, Ocean and Space Studies, Institute of Interdisciplinary Studies, University of Allahabad, Uttar Pradesh, India enhanced the model through adding more accurate spatial information of rainfall erosivity.

Keywords RUSLE - DEM · TRMM · Landsat ·

Watershed $\cdot$ Potential soil erosion risk

\section{Introduction}

Owing to its direct and indirect consequences on environment and economy, soil erosion has become a relevant worldwide issue. It is a slow dynamic natural process which involves detachment, transportation, and accumulation of productive surface soil across the earth's surface though water or wind action (Jain et al. 2001). The environmental factors responsible for soil erosion are rainfall erosivity, soil erodibility, land cover and topography. This natural process may turn into hazardous one if the amount of soil loss exceeds its normal level as a result of intensified anthropogenic activities such as land clearance, agriculture (ploughing and irrigation), overgrazing, deforestation, construction, surface mining, and urbanization. Soil erosion is being perceived as a serious matter of concern in several countries with having aggravated problem of unscientific agricultural practices and improper land management (Lal 2003).

Soil erosion and related land degradation has a chain of direct and indirect consequences leading to serious environmental, economical and social problems. The removal of fertile soil from the upper layer of soil profile causes loss of soil nutrients which in turn reduces agricultural productivity (Lal 1998). The eroded soil particles increase the deposition of sediment in lakes, reservoirs, canals and rivers and thus reduce the water capacity of fresh water reservoirs. With the increasing amount of suspended 
materials in waterbody, aquatic ecosystem gets affected. Also, the harmful pesticides, chemicals present in agricultural land causes water pollution and eutrophication through the process of soil erosion and transportation (Nyakatawa et al. 2001; Zhou et al. 2008; Wang et al. 2009). Intense soil erosion has several indirect impacts including increasing risk of floods, economic losses in irrigation and hydroelectric projects etc. (Arya and Samra 2001). It has been estimated that 329 Mha, constituting about $53 \%$ of the total geographical area of India suffers from deleterious effect of soil erosion with an annual average soil erosion rate of $16 \mathrm{t} \mathrm{h}^{-1}$ year ${ }^{-1}$ (Jain et al. 2001; Srinivas et al. 2002; Pandey et al. 2009). It has been estimated that in India about $5334 \mathrm{~m}$-tonnes of soil are being removed annually due to various reasons (Narayan and Babu 1983; Pandey et al. 2007). Although, there are several attempts implemented by Govt. of India in order to control soil erosion and land degradation, lack of accurate information has hindered the process of proper conservation planning and management. The quantification of soil loss and estimation of risk is important for identifying areas exposed to severe erosion and implementation of proper land management program. The field based methods of soil loss quantification is time consuming and lack of sufficient sampling plot may constrain the reliability of actual spatial extent of area under soil erosion. So, monitoring and accurate mapping the spatial pattern of soil loss over a large area is really difficult owing to the time and cost involved in this traditional field based method ( $\mathrm{Lu}$ et al. 2004; Chen et al. 2011; Kumar and Kushwaha 2013).

Since 1930s, several models were developed for estimating the amount of soil loss which can be categorized into two groups i.e., physical and empirical models. Physical based models such as Water Erosion Prediction Project (WEPP), Areal Non-point Source Watershed Environment Response Simulation (ANSWERS), Limburg Soil Erosion Model (LISEM), European Soil Erosion Model (EUROSEM), Soil and Water Assessment Tool (SWAT) investigates erosion processes by synthesizing individual components and requires detailed database for all components (Bhattarai and Dutta 2007). Whereas, the empirical models like USLE (Universal Soil Loss Equation), MUSLE (Modified Universal Soil Loss Equation), and RUSLE (Revised Universal Soil Loss Equation) has become well accepted worldwide due to their simplicity, modest data demand and applicability over larger areas (Millward and Mersey 1999; Lu et al. 2004; Zhang et al. 2009; Perovic et al. 2013). However, USLE and Modified USLE (MUSLE) were criticized for their potentiality in prediction of spatial distribution of soil erosion (Wang et al. 2009). RUSLE, the revised version of USLE not only provides an estimation of soil loss at the plot scale, but also it represents the spatial distribution of soil erosion in an area (Renard et al. 1997; Youe-Qing et al. 2008). The combined use of geospatial technique and RUSLE model has been widely used for its simplicity and applicability over larger areas with better accuracy and low cost (Millward and Mersey 1999; Wang et al. 2003; Angima et al. $2003 \mathrm{Lu}$ et al. 2004; Krishna Bahadur 2009; Zhang et al. 2010; Demirci and Karaburun 2012; Pradeep et al. 2015). The present study envisages the application of RUSLE method using remote sensing and GIS technique for estimating the amount of soil erosion in Sanjal watershed of West Singbhum, Jharkhand, India.

\section{Study area}

The study area comprises Sanjal watershed of Kharkai river sub-basin lies in the West Singbhum district of Jharkhand between $85^{\circ} 17^{\prime}-86^{\circ} 05^{\prime} \mathrm{E}$ longitude and $22^{\circ} 10^{\prime}-$ $22^{\circ} 53^{\prime} \mathrm{N}$ latitude (Fig. 1). It covers an area of $1457 \mathrm{~km}^{2}$. Kharkai, the principal tributary of the Subarnarekha river is formed by the junction of two mountain streams rising in the eastern Kolhan range of hills, namely, the Terlo and the Koranjia. It originates from the Chhota Nagpur Plateau and after passing through the districts of West Singhbhum, Bokaro, Seraikela, East Sighbhum and Ranchi it merges with Subarnarekha at Sankchi near Jamshedpur. The area represents an undulating topography with low lying hilly

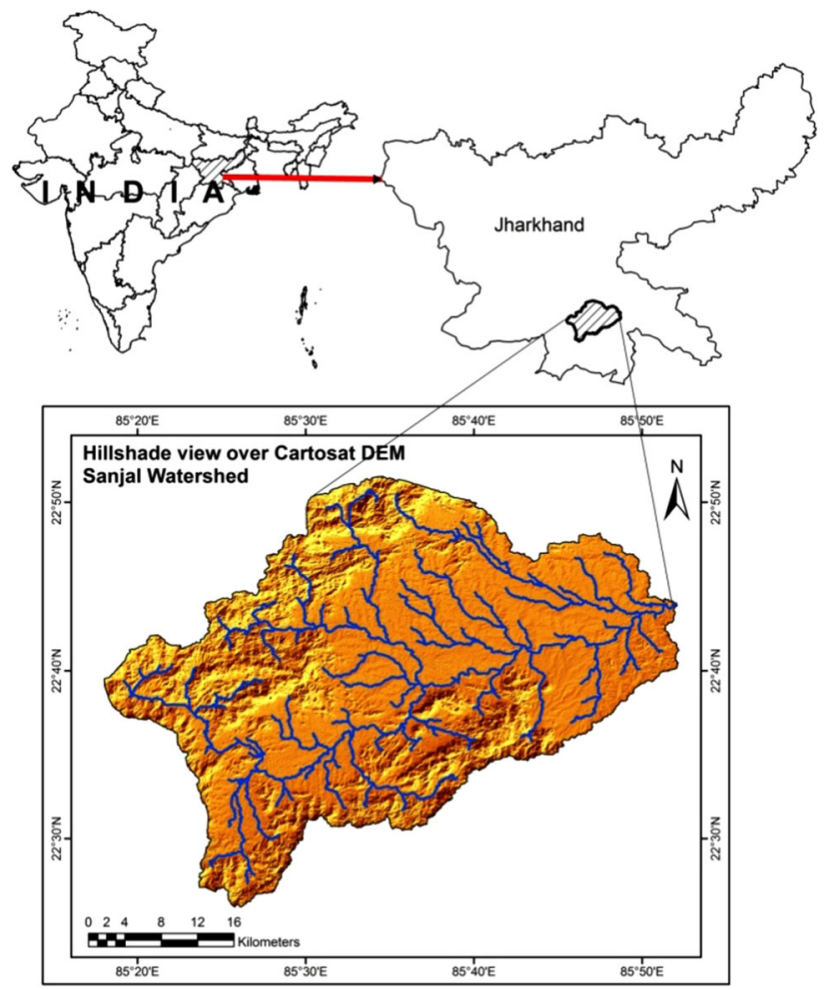

Fig. 1 Study area 
ranges in western part, adjoining plateaus and valleys stretching towards the eastern part. Elevation in this area is ranging between 806 and 102 meters above mean sea level. Geologically, the West Singbhum district comprises three major groups of rock structure: (a) granites and gneisses of Archaean age intrusive into the oldest sedimentary rocks, now highly metamorphosed, and known as the Singhbhum granite and gneiss, the Chotanagpur granite-gneiss, and the Chakradharpur and Akarsani granophyric granite-gneiss; (b) the Iron-ore Series which are mostly metamorphosed, ancient sediments with contemporaneous basic igneous rocks and are equivalent to a large part of the Dharwar System of Indian Geology, and (c) the volcanic lava flows of the Dalma hill and its adjoining ranges. This area is characterized by tropical climate with hot summer and mild winters. The mean monthly temperature varies between $40.5{ }^{\circ} \mathrm{C}$ during summer and $9.00{ }^{\circ} \mathrm{C}$ during winter. This area receives an annual rainfall of $1400 \mathrm{~mm}$ which occurs mainly during the months of July-August. The main soil types are Loamy, Coarse Loamy, Fine Loamy, Gravelly Loamy and Fine Soil. Agriculture is the dominant landuse pattern over the flat river plains of the study area whereas the hilly western part of the area is mainly covered by dense deciduous forest.

\section{Data and methods}

\section{Datasets used}

Landsat 8 satellite imagery acquired on 11th November, 2013 was used in this study for preparing landuse landcover map. Although the spatial resolution of this version of Landsat data is same as the earlier versions, it was selected for improved spectral and radiometric characteristics. This latest version of Landsat series has two-sensor payload, the Operational Land Imager (OLI) and the Thermal InfraRed Sensor (TIRS) which collects data for nine shortwave and two longwave thermal bands respectively. The Landsat OLI product comes with 12 bit radiometric and $30 \mathrm{~m}$ spatial resolution with having nine spectral bands of which two bands are newly added, a deep blue coastal/aerosol band for measuring water quality and a shortwave-infrared cirrus band for detecting high, thin clouds. IRS-P5 Cartosat-1 $2.5 \mathrm{~m}$ resolution data of 20th August, 2011 was used for generating DEM. The TRMM based monthly rainfall data for a period of 12 years (2001-2012) was collected from the NASA database. This dataset is a combined product of several precipitation datasets, i.e., Microwave Imager TMI, Precipitation Radar PR, Visible and Infrared Scanner VIRS with the Special Sensor Microwave Imager. Unlike the sparsely distributed meteorological station based rainfall data, this datasets provide pixel based rainfall data with 0.25 degree spatial resolution. TRMM provides high resolution vertical profiles $(250 \mathrm{~m})$ of precipitation through a $13.8 \mathrm{GHz}$ precipitation radar installed onboard (Heiblum et al. 2011). Since, the TRMM based precipitation estimates are merged product of multi-satellite observations, and gauge analyses (where feasible), it provides an uninterrupted coverage with high spatial and temporal resolution. Owing to its advantages over ground based raingauge stations, this data have been used widely for tracking tropical cyclones (Adler 2005). The TRMM based rainfall estimates are almost synchronized with ground based meteorological data making it acceptable worldwide for studying climatic as well as other environmental issues. Soil map of the area was obtained from State Agricultural Management and Extension Training Institute (SAMETI), Jharkhand. In order to collect field based information and verify the classified landuse landcover map, the area was visited during December, 2013 and ground control points were collected using a GPS.

\section{Model description}

The RUSLE model estimates amount of average annual soil loss as a combined function of rainfall-runoff erosivity, soil erodability, slope length and steepness factor, cover and management, conservation support-practices factor. It is one of the simplest and widely accepted models that can be applied for extensive areas and different contexts including forests, rangeland, hilly land, rugged terrain and degraded lands (Terranova et al. 2009). RUSLE is considered as one of the most effective method for assessing and predicting soil erosion caused by surface runoff in large areas at reasonable cost, time and accuracy (Ranzi et al. 2012). Owing to its improved capability to compute the soil erosion factors effectively, the model has been widely used for predicting average annual soil loss in both agricultural and forest watersheds (Renard et al. 1997). The average annual soil loss per unit area and per year was quantified as per the following equation (Eq. 1) of RUSLE (Renard et al. 1997)

$\mathrm{A}=\mathrm{R} \times \mathrm{K} \times \mathrm{LS} \times \mathrm{C} \times \mathrm{P}$

where, $\mathrm{A}$ is the average annual soil loss $\left(\right.$ ton $\mathrm{ha}^{-1}$ ) for a period selected for average annual rainfall; $\mathrm{R}$ is the rainfall erosivity factor (MJ mm ha ${ }^{-1} \mathrm{~h}^{-1}$ year $^{-1}$ ); $\mathrm{K}$ is the soil erodibility factor ( $\mathrm{t}$ ha h $\mathrm{MJ}^{-1} \mathrm{ha}^{-1} \mathrm{~mm}^{-1}$ ); $\mathrm{L}$ is the slope length and $\mathrm{S}$ slope steepness factor; $\mathrm{C}$ is the cover and management factor; and $\mathrm{P}$ is the conservation supportpractices factor. LS, $\mathrm{C}$ and $\mathrm{P}$ values are dimensionless. All these factors were mapped in raster GIS environment; so, the predicted average annual soil loss was obtained at pixel level. Since, the GIS based RUSLE model predicts 
potential soil loss at pixel level it can extract information on spatial heterogeneity as well as pattern of soil erosion in detail (Millward and Mersey 1999).

\section{Pre-processing of the datasets}

Before compiling all the factors, the raw datasets were georeferenced with Universal Transverse Mercators Projection using WGS 1984 datum. The boundary of Sanjal watershed was delineated from the Cartosat DEM using spatal analyst tool of ArcGIS (9.3) and it was used for subsetting the landsat image, TRMM images and soil map. The TRMM based monthly precipitation rate $(\mathrm{mm} / \mathrm{h})$ was converted into total monthly precipitation which was further averaged for estimating the average annual rainfall.

\section{Rainfall erosivity $(R)$ factor}

Rainfall erosivity is the major factor of RUSLE which is responsible for soil erosion over an area. It indicates the potential ability of a storm event to erode soil at a particular location. The $\mathrm{R}$ factor is estimated by total annual or seasonal rainfall erosivity of individual erosive storms which is calculated as the product of total storm energy and its maximum 30-min intensity (Wischmeier and Smith 1978). The kinetic energy of the falling raindrops is considered as the potential rainfall energy that determines the severity of erosion. However, lack of data on rainfall intensity and number of storms has constrained the implementation of original R equation of RUSLE. Since the rainfall erosivity is directly proportional to average annual rainfall, their relationship can be used as a proxy to estimate the R value (Arnoldus 1978; Singh et al. 1981; Kumar and Kushwaha 2013). The average annual rainfall of 12 years (2001-2012) as derived from TRMM data has used in the present study. In order to estimate the R factor, the following formula (Choudhury and Nayak 2003) was used.

$\mathrm{R}=79+0.363 \mathrm{Xa}$

where, $\mathrm{R}$ is the rainfall erosivity, $\mathrm{Xa}$ is the the average annual rainfall in $\mathrm{mm}$ over the study area.

\section{Soil erodibility $(K)$ factor}

Soil erodibility or K factor indicates susceptibility of soil to detachment of its particles and transport by rainfall. As the ability of soil to resist erosion depends upon the physiochemical properties of soil, the value of $\mathrm{K}$ factor varies with different types of soil. Soil erodibility is determined by several soil properties like texture or particle size distribution, organic matter content, permeability and nature
Table $1 \mathrm{~K}$ values for different soils

\begin{tabular}{lll}
\hline Sl. no. & Landuse/landcover type & K values \\
\hline 1. & Loamy soil & 0.310 \\
2. & Fine loamy soil & 0.232 \\
3. & Coarse loamy soil & 0.256 \\
4. & Gravelly loamy soil & 0.100 \\
5. & Fine soil & 0.120 \\
\hline
\end{tabular}

of clay minerals, of which soil texture is the most important factor for measuring erodibility. In this study soil erodibility was estimated by using the $\mathrm{K}$ values from different literature (Table 1).

\section{Slope length (LS) factor}

The slope length factor also known as gradient factor actually indicates the combined effect of slope steepness and slope length on rate of soil loss. The steeper and longer slope has higher potentiality to soil loss as they produce higher overland flow velocities and correspondingly higher runoff (Haan et al. 1994). The values of LS factor were computed using flow accumulation and slope steepness factor as derived from Cartosat DEM (Fig. 2). In this study, the following equation (Eq. 3) was used to calculate LS value recommended by Moore and Burch (1986).

$$
\begin{aligned}
\mathrm{LS}= & ([\text { Flow accumulation }] \times[\text { cell size }] / 22.13)^{0.4} \\
& \times(\text { sin slope } / 0.0896)^{1.3}
\end{aligned}
$$

where, LS is the slope length-slope steepness factor, cell size is the size of grid cell (for this study $30 \mathrm{~m}$ ) and $\sin$ slope is the slope degree value in sin.

\section{Cover and management $(C)$ factor}

The cover and management factor represents the ratio of soil loss under a given crop to that of the base soil (Morgan 1994). Vegetation cover prevents soil erosion by reducing the raindrop energy during rainfall. However, the amount of energy dissipated by vegetation depends upon percentage of vegetation cover and type of vegetation. The values of $\mathrm{C}$ factor ranges between 0 and 1 in which higher values represent dense vegetation cover and vice versa. Since course resolution satellite images are having limited utility in identifying crop types at plot level, NDVI has used as substitute for estimating $\mathrm{C}$ factor in many studies (De Jong et al. 1999; Zhou et al. 2008; Kouli et al. 2009). The $\mathrm{C}$ factor was determined using the following formula (Eq. 4).

$\mathrm{C}$ factor $=1.02-1.21 \times \mathrm{NDVI}$ 

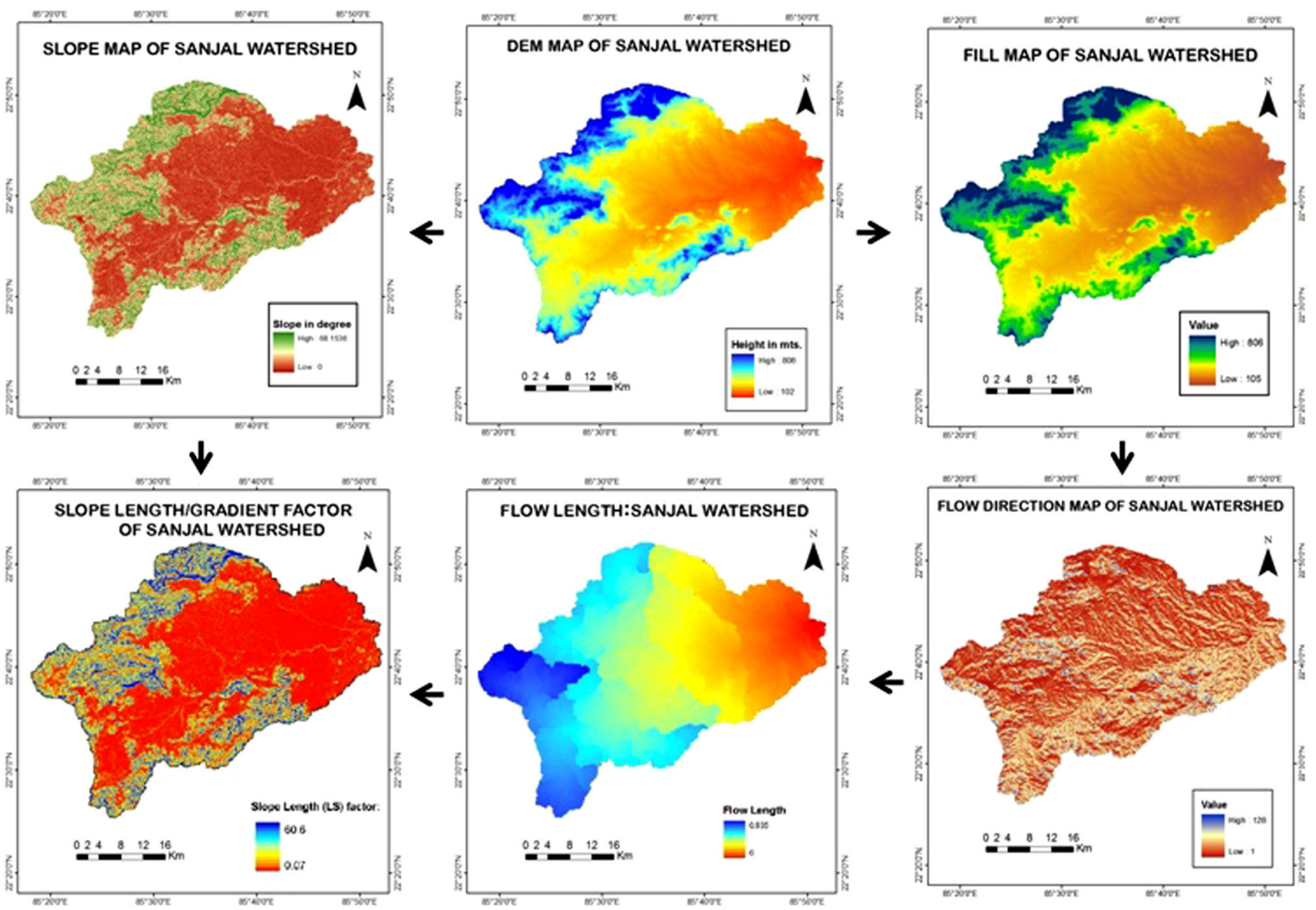

Fig. 2 Derivation of LS map

\section{Conservation practice $(P)$ factor}

The support practice or $\mathrm{P}$ factor represents the ratio between soil loss from a field with the given conservation practice to that where no conservation is practiced. When there are no conservation measures the value of $\mathrm{P}$ is 1.0 (Morgan 1986). The control practices reduce the rate of soil erosion by reducing the erosion potential of runoff through influencing the drainage patterns, concentration, velocity and hydraulic forces of runoff (Renard et al. 1997). The Landsat image was classified using Maximum Likelihood Classifier (Fig. 3) and pixels of each landuse and landcover classes were assigned $P$ value according to the list of USDA Handbook (1981) (Table 2).

\section{Results and discussions}

\section{RUSLE factors}

The average annual rainfall of 12 years (2001-2012) derived from TRMM data was used in the present study.

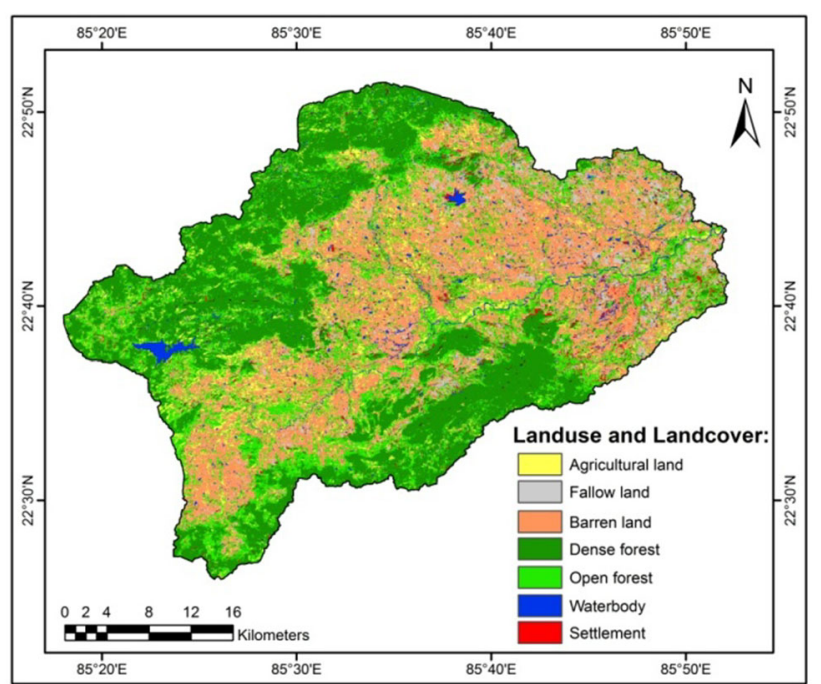

Fig. 3 LULC map

The TRMM derived rainfall estimates shows that the area receives an average annual rainfall ranging from 130 to $148 \mathrm{~cm}$. The mean and standard deviation of rainfall were 
Table $2 \mathrm{P}$ values assigned for different LULC classes

\begin{tabular}{lll}
\hline Sl. no. & Landuse/landcover type & P values \\
\hline 1. & Dense forest & 1.0 \\
2. & Open forest & 0.8 \\
3. & Water body & 1.0 \\
4. & Agricultural land & 0.5 \\
5. & Settlement & 1.0 \\
6. & Fallow land & 0.9 \\
7. & Barren land & 1.0
\end{tabular}

Source: USDA Handbook No. 282 (1981)

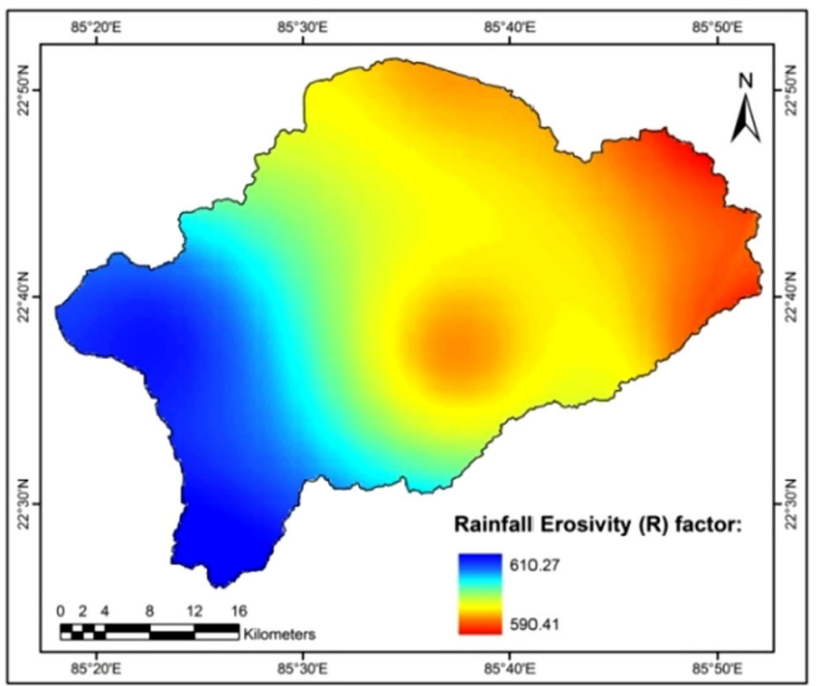

Fig. 4 Rainfall erosivity map

found $142 \mathrm{~cm}$ and 19.45 respectively. In order to estimate the LS factor the flow accumulation and slope steepness values derived from Cartosat DEM were used. The Landsat image was classified using Maximum Likelihood Classifier and P-value was assigned to each landuse and landcover class according to the list of USDA handbook. The spatial pattern of rainfall shows that there is a decreasing trend of rainfall from west to east of the study area that also coincides with the spatial pattern of rainfall erosivity $(\mathrm{R})$. The $\mathrm{R}$ values of the area were found ranging from 590 to $610 \mathrm{MJ} \mathrm{mm} \mathrm{ha}^{-1} \mathrm{~h}^{-1}$ year $^{-1}$ (Fig. 4). Soils in Sanjal watershed is mainly characterized by fine and gravelly loamy soils. The $\mathrm{K}$ value in the study area varies from 0 to 0.31 and the mean value was $0.0388 \mathrm{tha} \mathrm{h} \mathrm{MJ}^{-1} \mathrm{ha}^{-1}$ $\mathrm{mm}^{-1}$. The soils with higher values of $\mathrm{K}$ indicate higher susceptibility to soil erosion and vice versa (Kumar and Kushwaha 2013). It is evident from the soil erodibility map that most of the areas are having $\mathrm{K}$ value less than 0.12

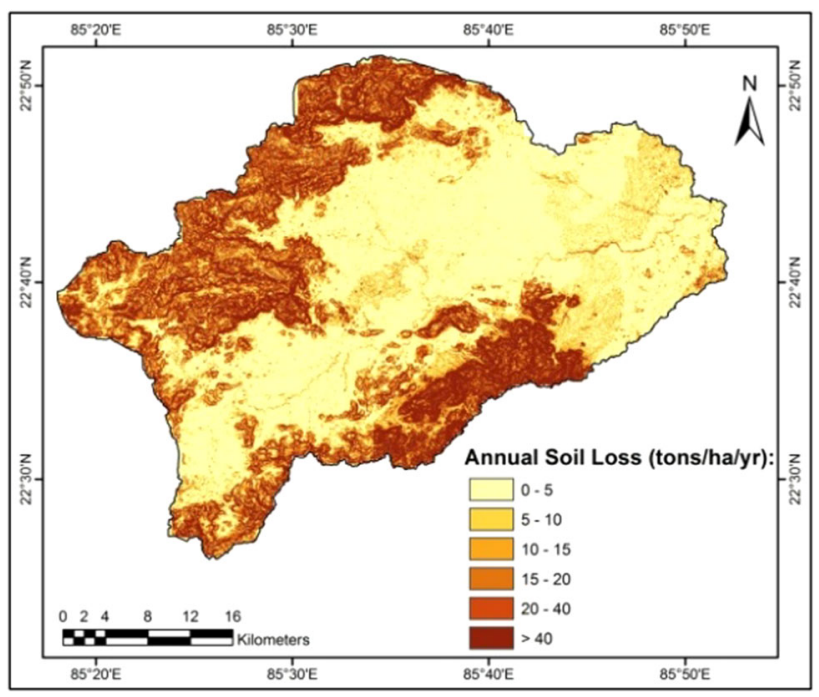

Fig. 5 Predicted annual soil loss

Table 3 Percentage of area under different erosion classes

\begin{tabular}{lll}
\hline Soil loss in $\mathrm{t} \mathrm{ha}^{-1}$ year $^{-1}$ & Erosion class & Area in percentage \\
\hline $0-5$ & Very low & 49.24 \\
$5-10$ & Low & 11.87 \\
$10-15$ & Moderate & 5.83 \\
$15-20$ & Moderately high & 4.09 \\
$20-40$ & High & 10.63 \\
$>40$ & Very high & 18.35 \\
\hline
\end{tabular}

except the south eastern part where the value is ranging between 0.12 and 0.31 . The Sanjal watershed is sloping towards the north east direction and bounded by low lying ridges in the North West and southern part. This part of the watershed has undulating terrain with higher elevation and steep slopes. The mean elevation (above mean sea level) of the watershed was found ranging from $806 \mathrm{~m}$ in the North West to $102 \mathrm{~m}$ in the eastern part. The slope gradient factor map shows that the LS value has become distinctly higher in this part. As a whole the LS value of the watershed is ranging between 0.07 and 60.6 with mean and standard deviation of 2.01 and 3.15 respectively. The land use land cover map of the area shows that one-fourth of the study area falls under dense forest which is mainly located in undulating and hilly terrain.

\section{Spatial pattern of predicted annual soil loss}

The predicted soil loss as calculated from five factors shows a distinguishable pattern which highly resembles with LS factor, forest cover and slope of the area. The 
Table 4 Area under different LULC classes and their respective average potential soil loss amount

\begin{tabular}{lccc}
\hline LULC & Area in $\mathrm{km}^{2}$ & Area $(\%)$ & Average erosion $\left(\mathrm{t} \mathrm{ha}{ }^{-1}\right.$ year $\left.^{-1}\right)$ \\
\hline Open forest & 356.17 & 24.45 & 14.93 \\
Settlement & 38.85 & 2.67 & 17.42 \\
Fallow land & 92.34 & 6.34 & 5.53 \\
Water body & 45.97 & 3.16 & 12.28 \\
Agricultural land & 103.08 & 7.08 & 6.61 \\
Dense forest & 405.74 & 27.85 & 66.79 \\
Barren land & 414.78 & 28.47 & 4.38 \\
Total & 1456.93 & 100.00 &
\end{tabular}

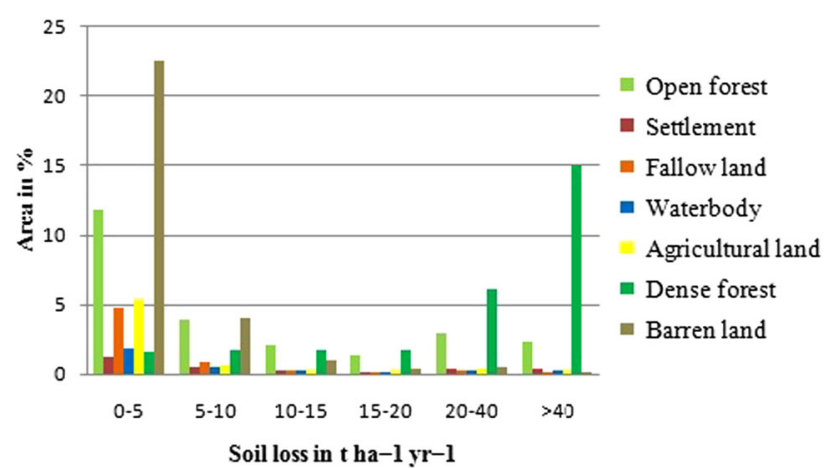

Fig. 6 Percentage of area under soil loss categories on different LULC classes

predicted amount of soil loss as estimated by RUSLE is ranging between 0.2 and $61.4 \mathrm{t} \mathrm{ha}^{-1}$ year $^{-1}$ in the study area which was further classified into five classes for further analysis (Fig. 5). The study predicts that about fifty percent of the area falls under very low $\left(<5 \mathrm{tha}^{-1}\right.$ year $\left.^{-1}\right)$ risk of soil erosion whereas eighteen percent of the area is having very high $\left(>40 \mathrm{t} \mathrm{ha}^{-1}\right.$ year $\left.^{-1}\right)$ risk of soil erosion (Table 3). It can be observed that the areas with very high soil erosion risk are mainly confined towards the north western and southern part of the watershed. The areas with low and very low risk of soil erosion can be found in the central part along the main river valley. The spatial pattern of soil erosion in this watershed can be explained by the land use land cover pattern and slope.

\section{Predicted annual soil loss on different LULC zones}

The estimated area under various LULC shows that the barren land and dense forest cover class accounts for more than half of the total area (Table 4; Fig. 6). Also, the area covered by open forest has notable proportion in the total area. However, Agricultural land and fallow land does not have major proportion in the total area under study. The average soil loss of these two LULC classes was found 6.61 and $5.53 \mathrm{t} \mathrm{ha}^{-1}$ year $^{-1}$ respectively (Table 4). Since the agricultural practices are mostly performed in plain land, the risk of soil erosion has become negligible. The study shows that the areas under dense forest are having maximum risk of soil erosion (Table 5). Although, there is a thick vegetation cover protecting the soil underneath the potential risk has become comparatively high in those areas. This is because the forests in the northwest and southern borders are mostly lying over dissected hilly terrain with steep slopes. It is noteworthy that the LS factor plays a significant role compared to other factors while estimating potential risk of soil erosion and thereby, a forested land can have higher risk if it is situated over steep slopes and rugged land (Yadav et al. 2005; Kumar and Kushwaha 2013). The average soil erosion over open forest and settlement was estimated to be 14.93 and $17.42 \mathrm{t} \mathrm{ha}^{-1}$ year $^{-1}$ respectively. It can also be explained by the gentle to undulating slopes present in those regions. As a whole, the study reveals a close agreement between erodibility of

Table 5 Percentage of area under various soil erosion classes and LULC types

\begin{tabular}{|c|c|c|c|c|c|c|c|}
\hline \multirow[t]{2}{*}{ Soil loss in $\mathrm{t} \mathrm{ha}^{-1}$ year $^{-1}$} & \multicolumn{7}{|c|}{ LULC (area in percentage) } \\
\hline & Open forest & Settlement & Fallow land & Water body & Agricultural land & Dense forest & Barren land \\
\hline $0-5$ & 11.84 & 1.21 & 4.80 & 1.82 & 5.38 & 1.55 & 22.61 \\
\hline $5-10$ & 3.85 & 0.46 & 0.86 & 0.51 & 0.57 & 1.66 & 3.97 \\
\hline $10-15$ & 2.07 & 0.23 & 0.26 & 0.22 & 0.29 & 1.73 & 1.02 \\
\hline $15-20$ & 1.39 & 0.14 & 0.12 & 0.13 & 0.20 & 1.73 & 0.38 \\
\hline $20-40$ & 2.93 & 0.31 & 0.18 & 0.25 & 0.43 & 6.10 & 0.43 \\
\hline$>40$ & 2.35 & 0.31 & 0.11 & 0.23 & 0.23 & 14.95 & 0.18 \\
\hline
\end{tabular}


Table 6 Percentage of area under soil loss categories on different slope zones

\begin{tabular}{lcclll}
\hline Soil loss in $\mathrm{ha}^{-1}$ year $^{-1}$ & $\begin{array}{l}\text { Gentle } \\
\left(0^{\circ}-5^{\circ}\right)\end{array}$ & $\begin{array}{l}\text { Undulating } \\
\left(5^{\circ}-15^{\circ}\right)\end{array}$ & $\begin{array}{l}\text { Hilly } \\
\left(15^{\circ}-25^{\circ}\right)\end{array}$ & $\begin{array}{l}\text { Steep } \\
\left(25^{\circ}-40^{\circ}\right)\end{array}$ & $\begin{array}{l}\text { Very steep } \\
\left(>40^{\circ}\right)\end{array}$ \\
\hline $0-5$ & 48.497 & 0.569 & 0.150 & 0.024 & 0.001 \\
$5-10$ & 8.273 & 3.594 & 0.000 & 0.000 & 0.000 \\
$10-15$ & 1.515 & 4.313 & 0.000 & 0.000 & 0.000 \\
$15-20$ & 0.715 & 3.370 & 0.000 & 0.000 & 0.000 \\
$20-40$ & 0.414 & 10.029 & 0.182 & 0.000 & 0.000 \\
$>40$ & 0.000 & 8.266 & 8.992 & 1.022 & 0.073 \\
\hline
\end{tabular}

soil and LS factor which acts as major driving factor of soil erosion over there.

\section{Predicted annual soil loss on different slope zones}

In order to analyze the role of slope on the degree of soil erosion risk, the area under potential soil loss was extracted for several slope zones (Table 6). The analysis of the potential risk of soil erosion on different slope zones reveals that areas under high and very high risk of soil erosion is predicted mainly over the hilly areas with steep and very steep slopes. Whereas, near about (48.49\%) fifty percent of the area under less than $5 \mathrm{t} \mathrm{ha}^{-1}$ year $^{-1}$ potential soil loss was found on the gentle slope $\left(0^{\circ}-5^{\circ}\right)$. It proves that the pattern of potential risk zones is highly related to the degree of slope and a close agreement can be found between them.

\section{Conclusions}

The study shows the potential use of TRMM data and geospatial technology for identifying the areas with potential risk of soil erosion. The RUSLE model has successfully estimated the potential degree of soil erosion risk over the area. It was found from the study that low to very low risk of soil erosion is mainly associated with agricultural and fallow land followed by barren land which is situated mainly on gentle and undulating slopes. About fifteen percent of the total area under dense forest cover situated in hilly terrain is predicted to be under very high risk of soil erosion. There is a close agreement between the degree of soil erosion risk and slope of the area; higher slopes are more susceptible to soil loss and vis-a-vis. The potential high and very high risk of soil erosion zone of the watershed demands proper land management practices for a sustainable level of living. The study also reveals that TRMM based rainfall data can be used as a substitute of rain gauge data for estimating spatial pattern of rainfall intensity, the R factor of RUSLE model. Since R factor is one of the most important drivers of soil erosion risk and amount of rainfall and its intensity varies spatially, this study suggests application of TRMM data for proper estimation of soil erosion risk.

Acknowledgments We are acknowledging the NASA for providing the TRMM, Landsat 8 data and NRSC, ISRO for Cartosat DEM. The authors are also grateful to Vidyasagar University and IIT-Kharagpur, West Bengal, India for providing necessary support to fulfill the study.

\section{References}

Adler RF (2005) Estimating the benefit of TRMM tropical cyclone data in saving lives. American meteorological society, 15th Conference on Applied Climatology, Savannah

Angima SD, Stott DE, O’Neill MK, Ong CK, Weesies GA (2003) Soil erosion prediction using RUSLE for central Kenyan highland conditions. Agric Ecosys Environ 97:295-308

Arnoldus HMJ (1978) An approximation of the rainfall factor in the Universal Soil Loss Equation. In: De Boodt M, Gabriels D (eds) Assessment of erosion. Wiley, Chichester, pp 127-132

Arya SL, Samra JS (2001) Revisiting watershed management institutions in Haryana Shivaliks, India; Annual Report CSWCRTI, Research Centre, Chandigarh, pp 104-105

Bhattarai R, Dutta D (2007) Estimation of soil erosion and sediment yield using GIS at catchment scale. Water Resour Manage 21:1635-1647

Chen T, Niu R, Li P, Zhang L, Du B (2011) Regional soil erosion risk mapping using RUSLE, GIS, and remote sensing: a case study in Miyun Watershed, North China. Environ Earth Sci 63:533-541

Choudhury MK, Nayak T (2003) Estimation of soil erosion in Sagar Lake catchment of Central India. In: Proceedings of the International Conference on Water and Environment, Dec 15-18, 2003, Bhopal, India, pp 387-392

De Jong SM, Paracchini ML, Bertolo F, Folving S, Megier J, De Roo APJ (1999) Regional assessment of soil erosion using the distributed model SEMMED and remotely sensed data. Catena 37:291-308

Demirci A, Karaburun A (2012) Estimation of soil erosion using RUSLE in a GIS framework: a case study in the buyukcekmece lake watershed, northwest Turkey. Environ Earth Sci 66:903-913

Haan CT, Barfield BJ, Hayes JC (1994) Design hydrology and sedimentology for small catchments. Academic Press, New York

Heiblum RH, Koren I, Altaratz O (2011) Analyzing coastal precipitation using TRMM observation. Atmos Chem Phys 11:13201-13217

Jain SK, Kumar S, Varghese J (2001) Estimation of soil erosion for a Himalayan watershed using GIS technique. Water Resour Manage 15:41-54 
Kouli M, Soupios P, Vallianatos F (2009) Soil erosion prediction using the Revised Universal Soil Loss Equation (RUSLE) in a GIS framework, Chania, Northwestern Crete, Greece. Environ Geol 57:483-497

Krishna Bahadur KC (2009) Mapping soil erosion susceptibility using remote sensing and GIS: a case of the Upper Nam Wa Watershed, Nan Province, Thailand. Environ Geol 57:695-705

Kumar S, Kushwaha SPS (2013) Modelling soil erosion risk based on RUSLE-3D using GIS in a Shivalik sub-watershed. J Earth Syst Sci 122:389-398

Lal R (1998) Soil erosion impact on agronomic productivity and environment quality: critical reviews. Plant Sci 17:319-464

Lal R (2003) Soil erosion and the global carbon budget. Environ Int 29:437-450

Lu D, Mausel P, Batistella M, Moran E (2004) Comparison of landcover classification methods in the Brazilian Amazonia basin. Photogram Eng Remote Sens 70:723-731

Millward AA, Mersey JE (1999) Adapting the RUSLE to model soil erosion potential in a mountainous tropical watershed. Catena 38:109-129

Moore ID, Burch GJ (1986) Physical basis of the length slope factor in the Universal Soil Loss Equation. Soil Sci Soc America J 50:1294-1298

Morgan RPC (1986) Soil erosion and conservation. Essex, Longman Group UK Ltd, p 295

Morgan RPC (1994) Soil Erosion and Conservation, Silsoe College, Cranfield University

Narayan VVD, Babu R (1983) Estimation of soil erosion in India. J Irrig Drain Eng 109:419-434

Nyakatawa EZ, Reddy KC, Lemunyon JL (2001) Predicting soil erosion in conservation tillage cotton production systems using the revised universal soil loss equation (RUSLE). Soil Tillage Res 57:213-224

Pandey A, Chowdary VM, Mal BC (2007) Identification of critical erosion prone areas in the small agricultural watershed using USLE, GIS and remote sensing. Water Resour Manage 21:729-746

Pandey A, Mathur A, Mishra SK, Mal BC (2009) Soil erosion modeling of a Himalayan watershed using RS and GIS. Environ Earth Sci 59:399-410

Perovic V, Zivotic L, Kadovic R, Jaramaz D, Mrvic V, Todorovic M (2013) Spatial modeling of soil erosion potential in a mountainous watershed of South-Eastern Serbia. Environ Earth Sci 68:115-128

Pradeep GS, Ninu Krishnan MV, Vijith H (2015) Identification of critical soil erosion prone areas and annual average soil loss in an upland agricultural watershed of Western Ghats, using analytical hierarchy process (AHP) and RUSLE techniques. Arab J Geosci 8:3697-3711
Ranzi R, Le TH, Rulli MC (2012) A RUSLE approach to model suspended sediment load in the Lo river (Vietnam): effects of reservoirs and land use changes. J Hydrol 422-423:17-29

Renard KG, Foster GR, Weesies GA, McCool DK, Yoder DC (1997) Predicting soil erosion by water: a guide to conservation planning with the revised universal soil loss equation (RUSLE). USDA Agricultural Handbook, No. 703

Singh G, Rambabu VV, Chandra S (1981) Soil loss prediction research in India, ICAR Bullet, T12/D9. CS WCTRI, Dehradun

Srinivas CV, Maji AK, Reddy GPO, Chary GR (2002) Assessment of soil erosion using remote sensing and GIS in Nagpur district, Maharashtra for prioritization and delineation of conservation units. J India Soc Remote Sens 30:197-212

Terranova O, Antronico L, Coscarelli R, Iaquinta P (2009) Soil erosion risk scenarios in the Mediterranean environment using RUSLE and GIS: an application model for Calabria (southern Italy). Geomorphol 112:228-245

United States Department of Agriculture USDA, Handbook no. 282 (1981)

Wang G, Gertner G, Fang S, Anderson AB (2003) Mapping multiple variables for predicting soil loss by geo- statistical methods with TM images and a slope map. Photogram Eng Remote Sens 69:889-898

Wang G, Hapuarachchi P, Ishidaira H, Kiem AS, Takeuchi K (2009) Estimation of soil erosion and sediment yield during individual rainstorms at catchment scale. Water Resour Manage 23:1447-1465

Wischmeier WH, Smith DD (1978) Predicting rainfall erosion losses: a guide to conservation planning. USDA Handbook, No. 537

Yadav RP, Aggarwal RK, Bhattacharyya P, Bansal RC (2005) Infiltration characteristics of different aspects and topographical locations of hilly watershed in Shivalik-lower Himalayan region in India. India J Soil Conserv 33:44-48

Youe-Qing X, Xiao-Mei S, Xiang-Bin K, Jian P, Yun-Long C (2008) Adapting the RUSLE and GIS to model soil erosion risk in a mountains karst watershed, Guizhou Province, China. Environ Monit Assess 141:275-286

Zhang Y, Degroote J, Wolter C, Sugumaran R (2009) Integration of modified universal soil loss equation (MUSLE) into a GIS framework to assess soil erosion risk. Land Degrad Develop 20:84-91

Zhang YG, Nearing MA, Zhang XC, Xie Y, Wei H (2010) Projected rainfall erosivity changes under climate change from multimodel and multiscenario projections in Northeast China. J Hydrol 384:97-106

Zhou P, Luukkanen O, Tokola T, Nieminen J (2008) Effect of vegetation cover on soil erosion in a mountainous watershed. Catena 75:319-325 